特異な像を呈した耳下腺良性多形腺腫の 2 例

\author{
谷垣内由之・吉田 博一 \\ 島田均・馬場廣太郎
}

\title{
Benign Pleomorphic Adenoma of Parotid Gland with Unusual Course and Histological Findings; Report of Two Cases
}

\author{
Yoshiyuki Tanigaito, Hirokazu Yoshida, \\ Hitoshi Shimada and Kotaro Baba \\ (Dokkyo University School of Medicine)
}

\begin{abstract}
Two female patients aged 37 and 46-years visited our out-patient clinic complaining of a tumor of the right parotid gland. A few weeks after the first visit, the tumors had become smaller. X-ray CT examinations of each patient showed a ring-shaped mass enhanced by the contrast medium in the lateral lobe of the parotid gland. The clinical course and the results of examinations led to a diagnosis of lymphadenitis or inflammatory cystic lesion. Both tumors were surgically extirpated, and histological examination showed benign pleomorphic adenoma with a wide area of central necrosis. The cause of the central necrosis is unknown. This type of benign pleomorphic adenoma is very rare but calls our attention to its possibility and the importance of accurate diagnosis and appropriate therapy.
\end{abstract}

Key words: benign pleomorphic adenoma, uncommon presenting history, histological finding

はじめに

耳下腺良性多形腺腫は, 緩慢に増殖する腫瘍 として知られている. その増大速度は遅く, 直 径が 2 倍になる平均が 5 年と言われている1). 当科に拀いても，気付いてから手術まで30年と いら例がある。しかしながら, 増大は絶えず進 行し, 通常縮小寸ることはないと考えられる. 本腫瘍は周团に薄い結合織の被膜を持ち, 組織 学的には多彩な像を呈する.内部には, 時に囊 胞を含むが, 出血, 壊死は認めないとされ る2)3).
我々は今日まで, 経過中腫瘍の縮小傾向を認 め, 切除腫瘍の中心部に広範な壊死を認めた 2 例の耳下腺良性多形腺腫を経験した。診断治療 上注意が必要と思われるので報告する。

\section{症例}

症例 1.37 歳, 女性.

主訴：右耳下部腫瘤.

既往歴: 8 年前と 3 年前に帝王切開にて出産, 同時に糖尿病を指摘された。

家族歴：特記すべきことなし.

現病歴: 平成 3 年 1 月, 右耳下部腫脹に気付 
いた、軽度の圧痛を伴い徐々に大きくなってき たが，放置していた。3 月，鼻閉のため近医耳 鼻咽喉科を受診, 鼻茸, 鼻アレルギーと診断さ れた。同時に右耳下腺部腫瘤を指摘され，精査 治療目的で当科を紹介され来院した.

初䛦時所見：右耳下部に $30 \times 25 \mathrm{~mm}$, 表面 平滑で硬い腫瘤を触孔た（図 1 )。圧痛があり， 可動性はやや不良であった。 顔面神経麻㽻, 頸 部リンパ節腫脹は認めなかった。両側鼻腔に鼻 咠を認めたが，他に耳，咽喉頭，口腔に著変は なかった。

検查所見抒よび経過：血液一般検査では異常 は認めなかった。ALP 10.3 KAU と軽度上昇

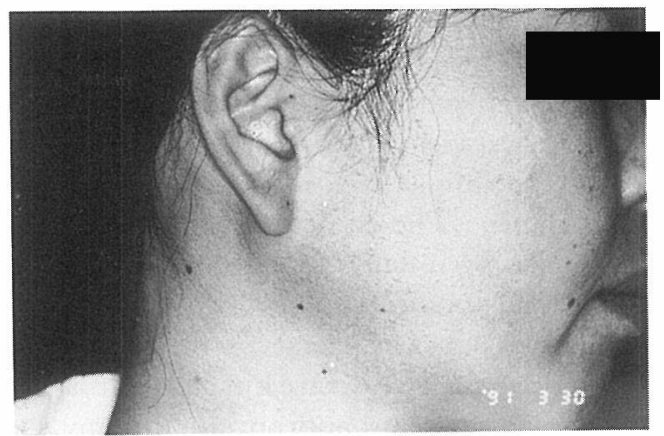

図 1 症例 1

右耳下部腫脹を認める.

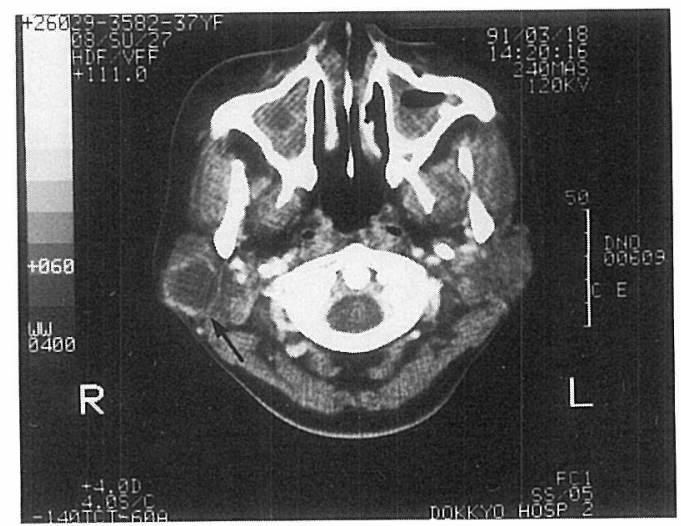

図 2 症例 $1 \quad \mathrm{X}$ 線 $\mathrm{CT}$ 検查 右耳下腺浅葉内にリング状に造影される 腫瘤陰影を認める $(\uparrow)$.
していたが，他に肝機能・電解質異常はなかっ た． 血糖值 $407 \mathrm{mg} / \mathrm{dl}$ と高值を示し，尿糖も2 $\mathrm{g} / \mathrm{dl}$ であった。胸部X線検査は正常であった。 EB ウイルス抗体価 VCAIgG (FA) 320 と高值を 示したため, 上咽頭耳管隆起上のやや不整な部 の生検を行ったが，リンパ組織の過形成のみで あった。

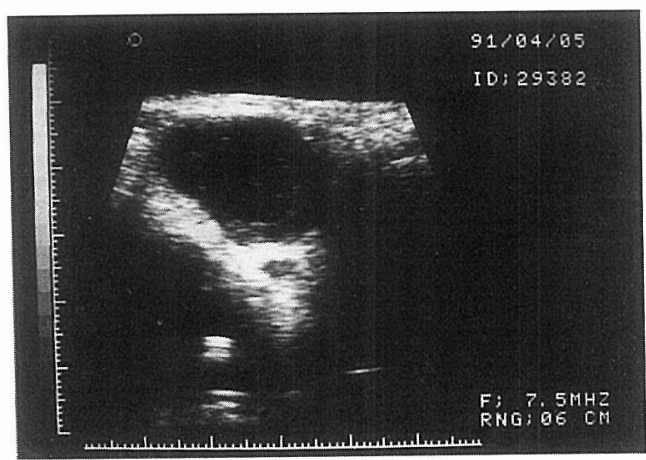

図 3 症例 1 超音波エコー検査 $27 \times 20 \mathrm{~mm}$ 大の腫瘤は, 境界が明膫で，内部エ コーを注とんど認めず，後方ェコーの増強があり 良性パターンを示す。

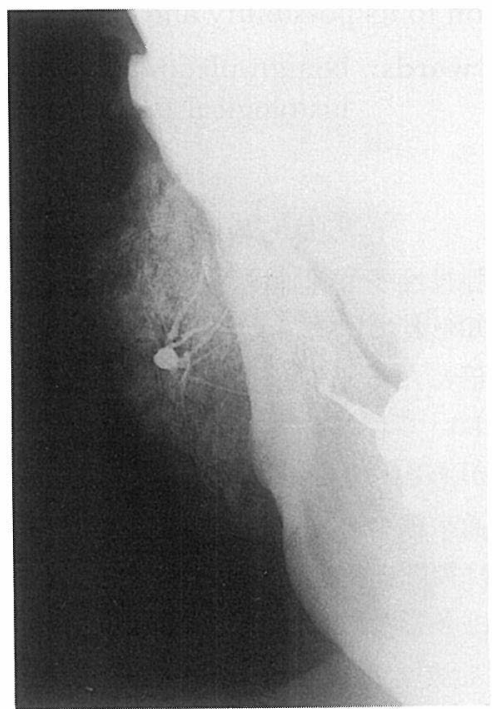

図 4 症例 1 耳下腺造影 炎症性変化, 漏洩や導管の断裂等の 悪性所見を認めない. 
副鼻腔 X線検査では, 両側副鼻腔炎の陰影を 認めた。耳下腺部 X線 CT 検查では, 右耳下腺 浅葉内に, 中心部の density が低く, 造影剂で 周囲がリング状に造影される腫瘤陰影を認めた。 境界は明瞭だが軽度凹凸不整を示した（図 2)。 超音波エコー検查では良性パターンであった (図 3 )。 ${ }^{67} \mathrm{Ga}$ シンチグラムでは，異常集積は なかった、耳下腺造影検査では，悪性所見はな く浅葉の腫瘤と思われた(図 4 ).

患者は CT 検査時腫瘤が増大し, その後縮小

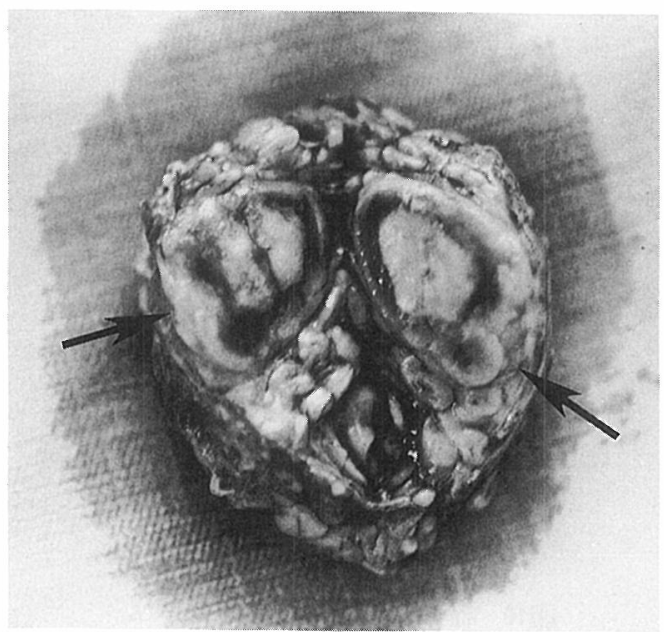

図 5 症例 1 切除組織と割面 耳下腺組織内の腫瘍 $(\rightarrow)$ は, 出血, 壊死を認める.

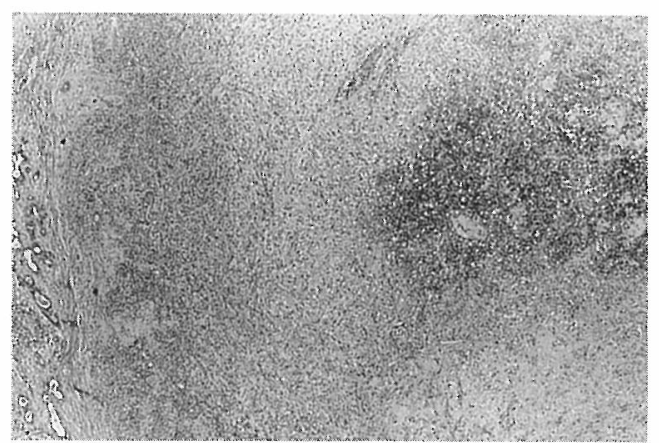

図 6 症例 1 病理組織像 $(\mathrm{HE}$ 染色 $\times 40)$ 左側飞腫瘍被膜を認める. 右側は腫瘍中心部で, 出血, 壞死を認める.
してきたと訴えた。初診から約 1 カ月で大きさ は20×20 mm に縮小した。

糖尿病はインスリンでュントロールし，リン ハ節病変むるいは埕胞性変化を示す良性腫瘍を 疑い手術を行った. 手術は通常の耳下腺腫瘍之 同様に行った。顔面神経を出し, 浅葉の腫瘤を 周囲耳下腺組織とともに，一塊に切除した。割 面では, 腫瘤は充実性で, 中心部は黄色に变化 していた。周囲は被膜で被われていた(図 5 ). 創を一期的に閉じ，手術を終了した。術後顔面 神経麻痺など合併症はなかった。

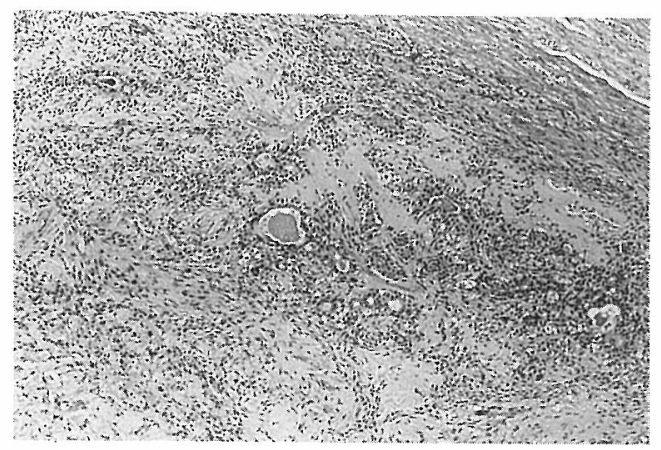

図 7 症例 1 病理組織像 $(\mathrm{HE}$ 染色 $\times 100)$ 右側上方に腫瘍被膜をみる。壊死海っていない 部は被膜内側直下に認められる。管腔形成と周团 の筋上皮系腫瘍細胞の増殖掞よび粘液腫状の間質 を認め多形腺腫と診断された。

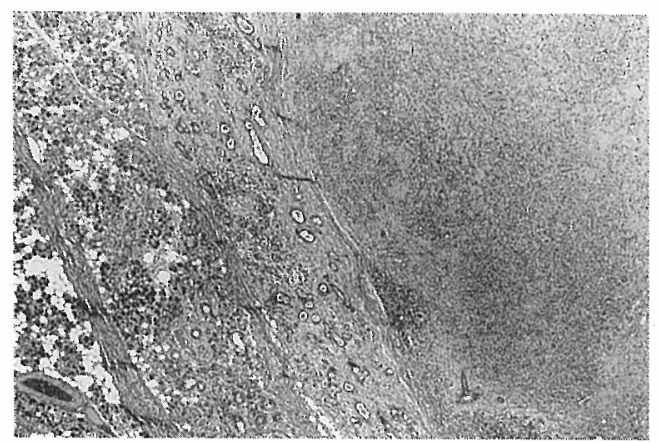

図 8 症例 1 病理組織像 $(H E$ 染色 $\times 40)$ 右側に腫瘍, 左側に周囲耳下腺組織, 中央部に腫 瘍被膜を認める。被膜近くには, リンパ球の浸潤 および高度に萎縮した耳下腺小葉組織を認める。 
病理組織学的には, 中心部が広範に壞死に陷 ってはいるものの, 周辺には典型的な多形腺腫 の像を認め，同診断がなされた。腫瘍は全周比 較的厚い被膜に被われていたが，娘腫瘍(腫瘍 細胞が集団で被膜外に突出した部)1〕認め, 被膜周囲には，リンパ球の浸潤と高度に萎縮し た耳下腺小葉組織を認めた(図 $6,7,8$ )。

症例 2.46歳，女性.

主訴 : 右耳下部腫脹.

既往歷 : 子宮脱

家族歷 : 特記すべきことなし。

現病歴：昭和 59 年 12 月， 60 年 2 月， 62 年 7 月 に右耳下腺部腫脹，疼痛が出現し抗生剂投与で 軽快した。63年 8 月 20 日再び耳下腺部痛, 腫脹 が生じたため来院した。 以前, 生理の時ピリピ リした痛みが同部に生じたことがあった。今回 も8月19日から生理であった。

初診時所見：右耳下部に $40 \times 43 \mathrm{~mm}$ 大の腫 瘤を認めた。硬く，皮膚に軽度の発赤を認めた， 他に異常は認めなかった。

検查所見特よび経過：血液一般検査，肝機能， 電解質に異常はなく，血中アミラーゼ 147 Dye U/d1 と正常であった。血沈は $26 \mathrm{~mm} / 1$ 時間

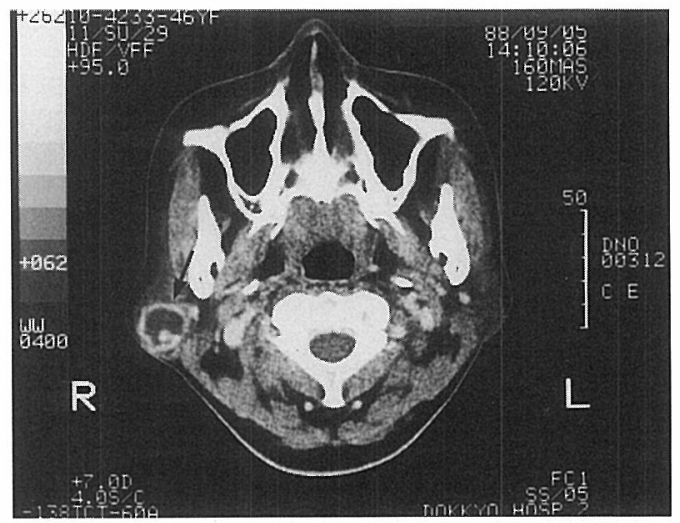

図 9 症例 2 X 線 CT 検查

右耳下腺内にリング状に造影される腫瘤を認める

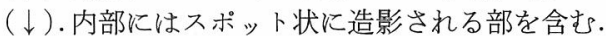

で，CRP 2.3 と高值を示した。ガムテストは $13 \mathrm{ml}$ で唾液分泌障害はなかった。

9 月 5 日の X線 CT 検査では，境界明瞭，凹 凸やや不整な腫瘤陰影が右耳下腺浅葉内に認め られた，腫瘤の周囲は造影剂でリング状に造影 され，中心部は low density で後方に一部スポ ット状に造影される部を認めた（図 9 )。99m Tc シンチグラムでは陰影欠損を示し(図10), ${ }^{67} \mathrm{Ga}$ シンチグラムでは腫瘤部の異常集積は明らかで

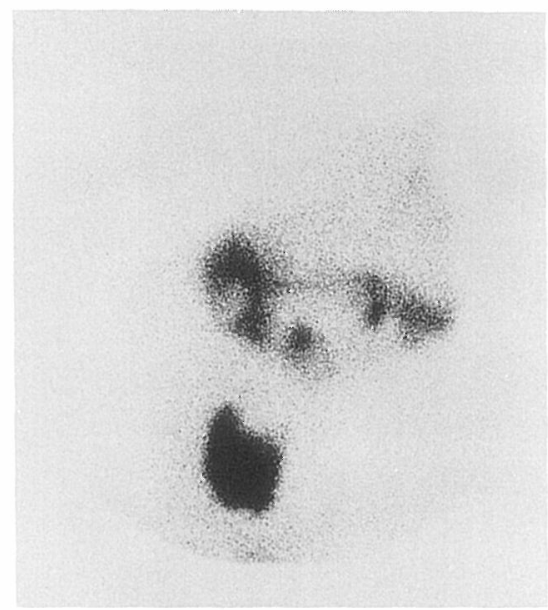

図10 症例 2 99m Tc シンチグラム 右耳下腺に腫瘍による欠損を認める。

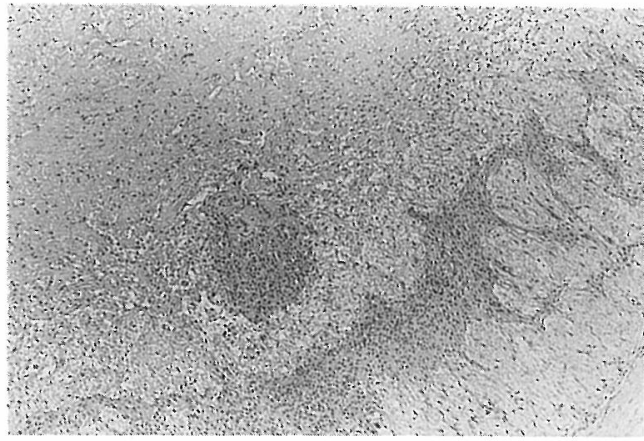

図11症例 2 病理組織像 $(\mathrm{HE}$ 染色 $\times 100)$ 右側下方に腫瘍被膜，左側上方に腫瘍中心部の壊 死をみる．腫瘍細胞は被膜内側直下にあり，粘液 腫状の間質の中に筋上皮系と考兄られる腫淘細胞 の増殖を認める。 
はなかった。超音波エコー検査では, 良性パター ンであった． 9 月 13 日に腫瘤は $15 \times 15 \mathrm{~mm}$ 大 に縮小した。

囊胞性疾患を疑い，手術を行った。腫瘤は， 胸鎖乳突筋直前の下部耳下腺にあり，顔面神経 を出すことなく周囲耳下腺組織を付け切除され た。

病理組織学的には, 症例 1 と同様中心部に壊 死を伴ら良性多形腺腫であった（図11）。腫瘍は 薄い被膜に被われていたが，娘腫瘍をあちこち に出す型のものであった.

術後顔面神経麻痺は認めず，軽快退院した。

\section{考察}

耳下腺には種々の腫瘤性病変が生じる．多く は腫瘍で, 中でも良性多形腺腫の頻度が高い. 多形腺腫は経過が長いのが特徵で，急激な増大 傾向は悪性化の示標の一つである。しかし逆に， 経過中縮小傾向をみることはないとされてい る1). 囊胞性変化を示す腺りンパ腫や, 同様の 変化を示す稀な型の多形腺腫4)では, 縮小傾向 を示す可能性があるが，経過中増大・縮小傾向 を示す場合，一般的には耳下腺内に多数含まれ る腺内リンパ節の炎症性変化5) や血管腫などの 血管病変1)，あるいは囊胞性疾患 ${ }^{416)}$ などが疑わ れる。

今回の症例のように圧痛や自発痛, 皮膚の発 赤などを伴っている例では，悪性腫瘍との鑑別 も必要となるが，悪性腫瘍では縮小傾向がない と考えてよいので，除外は容易である。しかし， 炎症性変化との鑑別は困難で，リンパ節病変・ 囊胞性疾患いずれとも䛊診される可能性がある。 $\mathrm{X}$ 線 CT 検查, MRI, 超音波エコー検查など を総合的に行えば，囊胞性病変は鑑別できるよ らに思われるが，X線 CT 検査で内部が均一に low densityを示したり，超音波ェュー検查で 内部エコーが汪とんどなく, 境界が明瞭で, 後 方ェコーの増強があり, cystic パターンと思わ れる場合などは，単一の検査のみで判断すると 囊胞と診断されることもあり，注意しなければ ならない。
耳下腺腫瘍の検査には種々あり, 総合的診断 が言われて久しい7)。しかしそのすべてを全例 に行らべきかどらかについては，時間とコスト の点で問題がある。それぞれの症例に応じて検 査項目を選ぶべきであろう。

現病歴や, 視・触診で悪性, 良性の大よその 見当のつくことが多い，当科では超音波エュー， $\mathrm{X}$ 線 CT 検査を第一選択としている. 悪性が疑 われる場合, 確定診断のため入院後 fine needle aspiration cytologyを行っている. 耳下腺 造影検査は手術前日にでも可能で，行う意義は ある。これらに対し RI 検查は, 検查待ち時間, コストなど患者負担の大きい割に得られる情報 量が少なく，全例に行ら必要のあるものではな い. MRI は場合によっては，X線 CT 検査で はっきりしない腫瘍を明瞭にすることができ有 用であるが，良性，悪性の情報については満足 できるものではない8)。検査の主目的は，良， 悪の鑑別である. 深葉, 浅葉の部位診断は, ど ちらに腫瘍があっても，手術治療上全く異なる 術式を行うのではない点に执いて意味があると 思之ない，画像診断の第 2 の目的は，良性の場 合の内部方向への進展の有無の確認, 悪性の場 合の切除範囲の決定にある.

症例 1 は, 初診時, 現病歴や局所所見から耳 下腺悪性腫瘍が疑われた。 しかし超音波エコー や，X線 CT 検査では悪性所見なく，手術まで の経過で縮小傾向を認め, 血液学的には炎症所 見を認めないものの腺内リンパ節炎が疑われた。 また初診時悪性が疑われたため予定された ${ }^{67} \mathrm{Ga}$ シンチグラムでは，異常集積を認めず，

囊胞性変化をもつ良性腫瘍も考えられた.

症例 2 は，長い期間に拈ける増大縮小の反復 と, X線 CT 打よび超音波エコー検査の結果か ら囊胞性疾患が疑われた．RI シンチグラムは, 受診時の局所所見から耳下腺内病変かどらかの 確認之，悪性病変の可能性も考兄予定されたが， 確定診断に到る情報は得られず，その後の著明 な縮小傾向から，術前診断として襄胞と誤診さ れた。 
検査機器の関係で施行されなかったが，本 2 例ともに MRI が施行されていれば，霊胞は除 外診断されていたと思われる.

炎症と良性腫瘍を鑑別する意味での ${ }^{67} \mathrm{Ga}$ シ ンチグラムをみると, 本 2 例のような, 長径 30 $\mathrm{mm}$ を越える大きさで，リンパ節炎などであれ ば，陽性を示すことが多いと思われる．本 2 例 ともに異常集積像を認めず, これが炎症と腫瘍 の鑑別点であったのかも知れない.

手術までの経過中悪性腫瘍が否定されたため fine needle aspiration cytology が行われず，多 形腺腫の診断を困難にしたと思われた。しかし 結果的にみると，たと光 fine needle aspiration cytology が施行されていたとしても，診断に 十分な細胞の得られるのは被膜直下のみであり, 確定診断に到るのは困難であったろらとも思わ れた。

いずれにしろ悪性疾患は否定され，2 例とも に深部への進展のない良性疾患と診断された。 当科では，耳下腺内病変で手術を行ら場合，た とえリンパ節炎などの疾患が考兄られても核出 術は行わない方針のため，本 2 例ともに周囲組 織をつけ切除された。

次に増大縮小の経過と組織所見についてみる 之, 症例 1 は, CT 検查時急激に増大し, その 後縮小傾向を示した. 静脈性造影剂による何ら かの影響があったのかも知れないが，他に CT 検査で同所見を示した例がなく明らかではない， 組織学的には被膜周囲にリンパ球の浸潤や周辺 小葉の著明な萎縮変化を認めたが，これらの所 見も時に認められるもので, 本例に特異なもの ではなく，造影剤による反応とは考えられない， 本例では糖尿病の合併があり，これによる血管 性病変が何らかの要因となったのかも知れない。

症例 2 では, 生理とともに耳下腺部痛が出現 し，ホルモン的な問題も考えられる. 2 例とも に娘腫瘍を外に突出する型であり, 増殖傾向と 血流あるいは間質の産生などのずれが壊死の原 因とも思われた。

組織所見から逆にみると，腫瘍被膜内側の壊
死化していない部が，X線 CT 検査で造影剤に より，リング状に造影されていたことがわかる. 同様所見は，悪性腫瘍のリンパ節転移や膿瘍な ぞでもしばしばみられる像である910)。本例で みられたリングの特徵は, 耳下腺内にあったこ 之, 比較的均一にリングが出ていたこと, 周囲 への浸潤像がなかったこと，形が凹凸不整を示 していたこと，内部が均一であったことなどで あった。

今回の症例は，現病歴，臨床所見，検査所見 から，腫瘍よりもリンパ節炎あるいは耳下腺囊 胞などが考えられた。しかし組織学的には，2 例ともに中心壊死を生じた多形腺腫であった。 手術治療を行う場合には，このような例の存在 も考光，リンパ節炎や囊胞などと診断されても 常に定型的手術を心掛け，核出術などの不十分 な手術を行らべきではないと思われた。

\section{まとめ}

1 ）経過中増大縮小傾向を示した 2 例の耳下 腺良性多形腺腫を報告した。

2) X線 CT 検査では，2 例とも造影剤でリ ング状に造影される耳下腺内腫瘤として認めら れた。

3) 超音波エコー検査, 耳下腺造影検査では, 良性パターンを示し， ${ }^{67} \mathrm{Ga}$ シンチグラムでは 異常集積を認めなかった。

4 ）組織学的には，2 例ともに中心部に広範 な壊死を認めた。

\section{文献}

1) 北村 武：耳下腺腫瘍の臨床像. 耳下腺腫瘍の 臨床 (奥田 稔編). 61 86頁, 医学教育出版社, 東京, 1984 .

2）下里幸雄，森永正二郎，斉藤裕夫：唾夜腺腫瘍 の病理. 耳下腺腫瘍の臨床 (奥田 稔編)．27～ 58頁, 医学教育出版社, 東京, 1984.

3）村上 泰：唾液腺良性腫瘍一多形腺腫に関寸 る最近の考方方一. JOHNS 2 : 391 401, 1986.

4）竹生田勝次：耳下腺囊胞. JOHNS 5 : 699 704, 1989.

5）行木英生：腺内リンパ節腫脹と耳下腺結核. 
JOHNS 2 : 385 389, 1986.

6) 田中克彦, 末永 通, 寺倉直明, 他 : 耳下腺囊 胞性疾患の臨床的検討. 日耳鼻 $89: 1796 \sim 1804$, 1986.

7）山下敏夫, 友田幸一, 二之湯修, 他 : 耳下腺部 腫瘍の総合診断 - RI, CT, 超音波一. 耳鼻臨 床 $71: 951 \sim 965,1978$.

8）宇野公一, 安西好美, 清水 昇, 他: 唾液腺の MRI. JOHNS 5 : 1435 1447, 1989.
9）杉本寿美子, 多田信平：咽頭疾患・頸部リンパ 節. JOHNS $12: 1259 \sim 1269,1986$.

10）加藤孝邦, 都志見格, 部坂弘彦, 他 : CT の適 応, 読影の要点. JOHNS $5:$ 699〜704, 1989.

原稿受付: 平成 3 年 6 月 19 日

原稿採択 : 平成 3 年 9 月 30 日

別刷請求先 : 谷垣内由之

†321-01 栃木県下都賀郡壬生町大字北小林 880
獨協医科大学耳鼻咽喉科学教室 